\title{
PHYTODIVERSITY AND SOIL STUDY OF SHIWALIK HILLS OF ILAM, NEPAL: AN ECOLOGICAL PERSPECTIVE
}

\author{
Ramkrishna Nirola* and Pramod Kumar Jha \\ Central Department of Botany \\ Tribhuvan University, Kirtipur, Kathmandu \\ *3/173 Park Terrace, Brahma Lodge, 5109 South Australia \\ E-mail: rknirola@gmail.com
}

\begin{abstract}
The Siwalik range (locally known as Churia hills) in Nepal comprise a total area of 1,886,000 ha, equivalent to $13 \%$ of the country's total area and consists of hills, steep land slopes, gorges, large spans of river and temporary streams. Study of different kinds of plants, soil and climate and the quantitative analysis of vegetation structure and composition as well as soil analysis at three Village Development Committees (VDCs) of Siwalik hills of Ilam was undertaken. A total number of 137 flowering plants and 8 pteridophytes are reported in the present study. Shorea robusta, Terminalia alata and Semecarpus anacardium are the most dominant species of the entire study area. The Siwalik range with late tertiary exposed rocks consists of fine grained sandstone with pockets of clay, shale, conglomerate and freshwater limestone. The vegetation is much more diverse and intact ecologically than expected from a distant observation.
\end{abstract}

Key words: Phytodiversity, vegetation, geology, soil, conservation, forest.

\section{INTRODUCTION}

The richness and diversity of plants on different parts of the planet is facing a disastrous decline in number. Reduction in forest cover often involves the fragmentation of habitats resulting into the reduction in the population of species leading into the loss of genetic diversity. Out of the over 7,000 vascular plant species recorded in Nepal, 22\% (1,570 species) are found in the Siwalik region. The vegetation of Ilam Siwaliks is represented either by deciduous or by semideciduous forms of vegetation (Aryal 1997). The vegetation category in Ilam Shiwaliks has been categorized into two; the lower tropical zone forest (below $500 \mathrm{~m} \mathrm{asl}$ ) and the upper tropical zone forest (500-1000 $\mathrm{m}$ asl) The lower tropical zone forest (below $500 \mathrm{~m}$ asl) consists of three vegetation types: i) Shorea robusta (Sal) forest, ii) Riverine Acacia catechu (Khair) and Dalbergia sissoo (Sisau) forest, iii) Pseudo-steppe with Graminae. The upper tropical zone forest (500$1000 \mathrm{~m}$ asl) consists of three vegetation types as follows: i) Shorea robusta (Sal), Terminalia alata (Saj) and Terminalia bellarica (Barro) forest, ii) Shorea robusta (Sal), Schima wallichi (Chilaune) forest, iii) Riverine Albizia (Siris), Adina (Karma) and Adina cordifolia (Toona) forest.

In order to know how different species grow on different soil types, it is necessary to study the soil characteristics. Usually, the soil found in 
Siwalik and Terai sal forest falls under the soil order Mollisols (Amatya and Shrestha 2002). The important properties affecting tree growth and forest regeneration are soil depth, soil texture, drainage, soil acidity, organic matter content and other soil nutrients. The plant diversity and soil properties are analyzed and characterized in this study.

\section{MATERIALS AND METHODS}

\section{Survey Area}

To distinguish a forest within a small altitudinal range of $200 \mathrm{~m}$ was impracticable without actually studying its diversity pockets, therefore, three sectors of Ilam Siwalks (southern foothills of Ilam district) having geographical contrasts were selected. These are:

Sector I: Southern Chulachuli Regenerating Forest Sector (SCRFS)

Sector II: North-East Danabari Matured Forest Sector (NEDMFS)

Sector III: South-West Mahamai Degraded Forest Sector (SWMDFS)

The study area lies between the map coordinates of $87^{\circ} 42^{\prime}$ and $87^{\circ} 57^{\prime} \mathrm{E}$ and $26^{\circ} 40^{\prime}$ and $26^{\circ} 48^{\prime} \mathrm{N}$ covering only the three above sectors. Forest plots were laid on nine different community forests in all the three sectors with each sector covering three-community forests. Out of the three types of land systems classified by Department of Soil Conservation, Nepal in 1987, the present study area falls under the last two of the North boundary ridge system, finely dissected by lowlands and Cresta Ridgeland and bottom land complex. The average mean monthly temperature over a year is $16.6^{\circ} \mathrm{C}$ in January and $25.8^{\circ} \mathrm{C}$ in July and August. The humidity is varying in a big range from $69 \%$ in April to $90 \%$ in July and August. The average annual precipitation is recorded up to 3000 $\mathrm{mm}$.

\section{SAMPLING STRATEGIES AND ANALYSIS}

From the base of the hill of a particular sector in the community forest, the plot sampling was initiated up to the highest altitude. The sample plot was marked with enamel by choosing a biggest tree, so that the plot can be considered as a centre. The plot was laid out around the central tree with the help of a measuring tape and nylon thread. Within the $10 \mathrm{~m} \times 10 \mathrm{~m}$ plots, all the trees over 15 $\mathrm{cm}$ circumferences at breast height $(\mathrm{CBH})$ were measured. Below $15 \mathrm{~cm} \mathrm{CBH,} \mathrm{the} \mathrm{tree} \mathrm{hardly}$ attained the breast height $(1.37 \mathrm{~m})$. In the sub-plots or $5 \mathrm{~m} \times 5 \mathrm{~m}$ plots, all the shrubs were recorded. Canopy cover was noted in each plot by visual estimation. To calculate the height of a tree, using clinometer from distance of $10 \mathrm{~m}$ away from the tree, angle was taken. Each species collected were tagged and identified with standard literature and local people. Within $1 \mathrm{~m} \times 1 \mathrm{~m}$ plots the number of herbs and grasses were recorded and each specimen were collected and tagged. All the measurements were made using standard methods. The cases such as fallen trees and branches, cut stumps, effects of fire, flood, etc. were also recorded. The unidentified specimens were tagged and identified by consulting the taxonomists at Tribhuvan University Central Herbarium (TUCH), Kirtipur and Kathmandu Herbarium (KATH) Godawari, Kathmandu, Nepal. The altitude and map coordinates for each plot was measured by Global Positioning System (Geo explorer GPS and Magallen 4000). The soil $\mathrm{pH}$ was taken on the spot using portable $\mathrm{pH}$ meter. The soil samples from a suitable plot below $15 \mathrm{~cm}$ was dug, packed and brought to Kathmandu for laboratory analysis. The sampling was done in two seasons extending for a period of 14 days during summer (June-July) and 42 days during autumn months.

\section{RESULTS AND DISCUSSION}

A community that contains few individuals of many species would have higher species diversity

ECOPRINT VOL 18, 2011 
than the same number of individuals but with most of them confined to a few species (Sai and Mishra 1986). In the present study, overall highest diversity including trees, shrubs and herbs in Sector I, supports the intermediate successional stage. In the Siwalik, the highest species diversity is recorded during September-October (Aryal 1997) which is further discussed below.

\section{Tree Species}

In the present investigation (Table 1), the highest tree density were observed in Sector I (SCRFS) followed by Sector II (NEDMFS) and Sector III (SWMDFS). It is due to a good conservation strategy adopted in Sector I and due to dry area which discouraged ground vegetation growth in Sector III. This result is similar to those of Pandey (2001) in Garwal Hills, and Bhuju and Yonzon (2000) in Churia (Siwalik) forest of eastern Nepal. The total tree density in sector I was 1087.5 plant $\mathrm{ha}^{-1}$ for Shorea robusta, almost similar to the findings of Adhikari et al. (1991) in Kumaun Himalayas. The density of plants in Ilam Siwalik area of Nepal for Shorea robusta is much lower as found in Sector II (346 pl. ha ${ }^{-1}$ ) and Sector III (175 pl. ha $\left.{ }^{-1}\right)$ in the present study. For Shorea robusta, Pandey (2001) in Garwal hills found the density to be $1111 \mathrm{pl}$. ha ${ }^{-1}$, Aryal (1997) in RBNP found 384.89 pl. ha ${ }^{-1}$, Giri et al. (1999) in RBNP found 152 pl. ha ${ }^{-1}$ and Bhuju and Yonzon (2000) in Eastern Nepal reported 756.5 pl. ha ${ }^{-1}$.

The most frequent tree species was Shorea robusta with $100 \%$ frequency in sectors I and II and $75 \%$ in sector III. The lower value of frequency in sector III is due to infertile and dry land, fire and felling for illegal trade of timber. The frequency of trees were less in Sector I which shows that due to less canopy cover in regenerating forest the competition among species is low and more diverse species are found.
The total basal area was found highest in Sector II which is a mature forest. The plants in Sector I were dense with taller and thinner stem. However, the average basal area of Shorea robusta was found lower than other species like Terminalia bellirica which is similar to the findings of study in Chitwan (Shrestha 2003). The Importance Value Index (IVI) in the present study revealed that in case of tree species, Shorea robusta has maximum IVI in all the three sectors (Table 1). The entire study area was dominated by sal forest characterised by acidic soil and generally dry habitat. Such observation was also recorded by Aryal (1997). The other species with higher IVI were Lagerstroemia parviflora, Cochlospermum religiosum, Terminalia alata, Terminalia bellirica in Sector I and in Sector II, Adina cordifolia, Schima wallichi, Semecarpus anacardium and Terminalia alata were with high IVI. While in Sector III Adina cordifolia, Albizia sp., Garuga pinnata and Semecarpus anacardium had higher IVI.

The lower IVI for Shorea robusta (60.95) in Sector I was due to the species diversity in the regenerating forest. In Sector II, the IVI for Shorea robusta was found highest, compared to the two other sectors because the forest is mature and people are strictly forbidden to cut down Shorea robusta pertaining to severe penalty. Moreover, lack of easy black-market access due to the remote location has helped save the valuable sal trees. The average IVI of Shorea robusta in the Siwalik area of Ilam is less than 90.66 in hill sal forest at Kavrepalanchowk district in central Nepal (Pant 1997). This shows that Shorea robusta is not yet to be considered as a most successful tree species in the study area. Although, the tree species were almost similar in diversity to that of Bharbandar forest studied by Shrestha (2003) and in Bardia by Aryal (1997), the shrub (and herb) species are found to be different. 
Table 1. Vegetation parameters of tree species.

\begin{tabular}{|c|c|c|c|c|c|c|c|}
\hline Sector I & D ha $^{-1}$ & $\mathbf{F} \%$ & TTV $\mathrm{m}^{3} \mathrm{ha}^{-1}$ & RD\% & RF\% & RBa\% & IVI \\
\hline 1. Shorea robusta & 1087.5 & 100 & 16527.9 & 47.0 & 12.7 & 1.23 & 60.95 \\
\hline 2. Cochlospermum religiosum & 37.5 & 25 & 51132.6 & 1.62 & 3.17 & 24.12 & 28.91 \\
\hline 3. Terminalia bellirica & 37.5 & 25 & 10154.2 & 1.62 & 3.17 & 13.39 & 18.18 \\
\hline \multicolumn{8}{|l|}{ Sector II } \\
\hline 1. Shorea robusta & 346.15 & 100 & 413623. & 8.00 & 37.5 & 19.11 & 64.61 \\
\hline Semecarpus anacardium & 176.92 & 92.3 & 33354.6 & 2.37 & 19.1 & 17.65 & 39.77 \\
\hline 3 Terminalia alata & 107.69 & 53.8 & 36146.8 & 3.24 & 11.6 & 10.29 & 25.20 \\
\hline \multicolumn{8}{|l|}{ Sector III } \\
\hline 1. Shorea robusta & 175 & 75 & 61174.2 & 13.68 & 30.43 & 18.75 & 62.86 \\
\hline 2 Adina cordifolia & 25 & 25 & 23523.2 & 27.35 & 4.34 & 6.25 & 37.94 \\
\hline 3. Semecarpus anacardium & 75 & 50 & 9709.9 & 7.14 & 13.04 & 12.5 & 32.68 \\
\hline
\end{tabular}

$\mathrm{D}=$ Density, F = Frequency, TTV = Tree Trunk Volume, RD = Relative Density, RF = Relative Frequency

$\mathrm{RBa}=$ Relative Basal Area, IVI = Importance Value Index

Table 2. Vegetation parameters of shrub species in different sectors of Siwalik hills of Ilam.

\begin{tabular}{|c|c|c|c|c|c|c|c|}
\hline \multicolumn{2}{|c|}{ Sectors } & Dha $^{-1}$ & $\mathbf{F} \%$ & RD\% & RF\% & RAb\% & IVI \\
\hline \multicolumn{8}{|c|}{ Sector I } \\
\hline 1. & Desmodium confertum & 1600 & 100 & 16.33 & 7.4 & 10.12 & 33.85 \\
\hline 2. & Osbeckia nepalensis & 800 & 50 & 2.04 & 3.7 & 10.12 & 21.98 \\
\hline 3. & Calotropis procera & 800 & 100 & 8.16 & 7.4 & 5.06 & 20.62 \\
\hline \multicolumn{8}{|c|}{ Sector II } \\
\hline 1. & Dichora febrifuga & 1200 & 100 & 18.75 & 12.5 & 12.24 & 43.49 \\
\hline 2. & Flemigia strobilifera & 1000 & 100 & 15.63 & 12.5 & 10.20 & 38.33 \\
\hline 3. & Begonia picta & 600 & 50 & 9.40 & 6.25 & 12.24 & 27.89 \\
\hline \multicolumn{8}{|c|}{ Sector III } \\
\hline 1. & Clerodendrum viscosum & 1600 & 100 & 23.52 & 16.67 & 23.52 & 63.70 \\
\hline 2. & Callicarpa macrophylla & 1200 & 100 & 17.64 & 16.67 & 17.64 & 51.95 \\
\hline 3. & Lantana camara & 800 & 100 & 11.80 & 16.67 & 11.76 & 40.23 \\
\hline
\end{tabular}

\section{Shrub Species}

In Sector I the highest shrub density was found for Desmodium confertum (1600 pl. $\left.\mathrm{ha}^{-1}\right)$. In Sector II it was Dichroa febrifuga (1200 pl. ha $\left.{ }^{-1}\right)$ and in Sector III it was 1600 pl. ha ${ }^{-1}$ for Osbeckia stellata and Clerodendrum viscosum (Table 2).The study shows that Dichora febrifuga thrives well in mature forest with wet condition and Desmodium confertum grows well in regenerating forests. In case of shrubs, in Sector I, Calotropis procera,
Desmodium confertum, Hibiscus radiatus, Lantana camara, Melastoma normale, Mussaenda erythrophylla had $100 \%$ frequency. In Sector II, Dichora febrifuga, Flemingia sp. and Phoenix humilis had $100 \%$ frequency, and in Sector III Callicarpa macrophylla, Clerodendruum viscosum, Osbeckia stellata had $100 \%$ frequency. Such result is due to the local environmental variables like aspect, humidity and temperature. The different environment and amount of rainfall received have made the under storey layers of 
herbs and shrubs different (Stainton 1972). In Sector I, shrub species like Desmodium confertum has higher IVI with 33.85 followed by Osbeckia nepalensis (21.98) and Calotropis procera (20.62). In Sector II shrub species like Dichroa febrifuga had highest IVI of 43.49 followed by Flemingia sp. (38.33) and Phoenix humilis (Table 2).

\section{Herb Species}

The presence of Oxalis corniculata being frequent in Sector II is due to the wet condition of soil. The presence of Thysanolaena maxima being more frequent in sector I shows that it can thrive best in well exposed soil and rock crevices which is found there. In case of herb species, Ageratum hustonianum (4285.70 pl. ha ${ }^{-1}$ ) was having high density in Sector I while in Sector II Cyperus rotundus $\left(7142.90 \mathrm{pl}\right.$. ha $\left.{ }^{-1}\right)$ was having high density and in Sector III, Breea arvensis (7142.8 pl. $\mathrm{ha}^{-1}$ ) had the highest density (Table 3 ). The result concludes that Breea arvensis thrives well in degraded land and dry area as found in case of Sector III of the present study. The highest frequency for herbs in Sector I is seen for species like Ageratum hustonianum (42.9\%), Thysanolaena maxima (41.43\%). In Sector II it was Cyperus rotundus (71.43\%), Oxalis corniculata $(64.28 \%)$ and Imperata cylindrica $(50 \%)$. In Sector III the most frequent herb species was Breea arvensis (71.4\%). The herb species like Ammannia baccifera, Lagerstroemia indica, Oxalis corniculata and Triumfetta rhomboides had highest IVI with 13.54. Cyperus rotundus had highest IVI with 39.95 followed by Oxalis corniculata (36.71). In Sector III shrub species like Clerodendrum viscosum and Osbeckia stellata had the highest IVI (63.70). Although Eupatorium odoratum was the most dominant herb in all the three sectors, it was avoided while sampling the plots. In disturbed forests, the invasive alien species grow luxuriantly and dominates the community. Different species in different sectors having the highest IVI show that the environmental and climatic factors play a major role in plant distribution.

The similarity index fits well with positive result based upon the analysis of IVI. The Sector I and Sector II vegetation had the highest similarly index. This is because of more care and protection rendered by the locals there. The range of similarity for the species in Sectors I and II was highest with $36.36 \%$. Floristic similarity is the response of species to the macro and micro environments. Although all the three sites have similar environmental conditions like temperature and rainfall, the floristic distribution is influenced by soil texture and nutrients in each sector.

\section{Soil Analysis}

Most of the soil samples were collected from the fertile part of the forest, the Sector III soil was found to be more acidic ( $\mathrm{pH}$ 5.6) than those of the other two sectors (Table 4). The forest in Sector III was more disturbed with low density of trees and higher density of grasses which use more bases resulting into the rise in $\mathrm{pH}$ level (Butler, 1995). Similar findings were recorded by Pant (1997) in sal forest at Gorkha, and Sigdel (1994) in Royal Chitwan National Park, Marasini (2003) in Rupandehi, Shrestha (2003) in Barandabhar forest. Soil nutrient level in Sector II in the present study was the highest having organic matter $2.63 \%$, nitrogen $0.13 \%$, phosphorous $34.8 \mathrm{~kg} \mathrm{ha}^{-1}$ and potassium $208.66 \mathrm{~kg} \mathrm{ha}^{-1}$. Similar results were obtained by Bhatnagar (1965) in sal forest. Organic matter is contributed by dead and decayed plant parts and obviously the mature forest in Sector II had the tendency to contribute more organic matter compared to Sectors I and II. 
Table 3. Vegetation parameters of herb species in different sectors of Siwalik hills of Ilam.

\begin{tabular}{lcccccc}
\hline Sector I & $\mathbf{D ~ h a}^{-1}$ & $\mathbf{F \%}$ & $\mathbf{R D} \%$ & $\mathbf{R F} \%$ & $\mathbf{R A b \%}$ & IVI \\
\hline 1. Ageratum hustonianum & 4285.7 & 42.9 & 6.06 & 6.06 & 3.44 & 15.56 \\
2. Oxalis corniculata & 3571.4 & 35.71 & 5.05 & 5.05 & 3.44 & 13.54 \\
3. Cyperus compressus & 3214.2 & 32.14 & 4.55 & 4.55 & 3.44 & 12.54 \\
Sector II & & & & & & \\
1. Cyperus rotundus & 7142.9 & 71.43 & 16.13 & 16.13 & 7.69 & 39.95 \\
2. Oxalis corniculata & 6428.6 & 64.28 & 14.51 & 14.51 & 7.69 & 36.71 \\
3. Imperata cylindrica & 5000 & 50.00 & 11.29 & 11.29 & 7.69 & 30.27 \\
Sector III & & & & & & \\
1. Breea arvensis & 7142.8 & 71.4 & 16.67 & 16.67 & 12.5 & 50.01 \\
2. Imperata cylindrica & 5714.3 & 57.1 & 13.3 & 13.3 & 12.5 & 39.10 \\
3. Sida rhombifolia & 4285.7 & 42.8 & 9.99 & 9.99 & 12.5 & 32.48 \\
\hline
\end{tabular}

Table 4. The soil characteristics of three sectors

\begin{tabular}{lccc}
\hline $\begin{array}{l}\text { Parameters of } \\
\text { Soil }\end{array}$ & Sector I & Sector II & $\begin{array}{c}\text { Sector } \\
\text { III }\end{array}$ \\
\hline $\mathrm{pH}$ & 6.06 & 6.20 & 5.60 \\
OM (\%) & 2.00 & 2.63 & 2.00 \\
Nitrogen (\%) & 0.09 & 0.13 & 0.09 \\
Phosphorous & 24.48 & 34.80 & 18.36 \\
kg ha $\left.^{-1}\right)$ & & & \\
Potassium & 180.51 & 208.66 & 199.76 \\
(kg ha $\left.{ }^{-1}\right)$ & & & \\
Percolation & 36.80 & 32.60 & 30.60 \\
$(\%)$ & & & \\
Water rising & 36.18 & 33.84 & 30.54 \\
$(\%)$ & & & \\
Water & 30.99 & 27.27 & 41.75 \\
Holding (\%) & & & \\
Fine sand (\%) & 36.30 & 36.40 & 16.22 \\
Silt (\%) & 52.70 & 47.52 & 64.19 \\
Clay (\%) & 11.05 & 15.97 & 19.57 \\
Colour & Dark & Light & Grey \\
& Grey & grey to & \\
\hline & & yellow & \\
\hline
\end{tabular}

Nitrogen content was higher in Sector II and the reason being more of biological fixation due to the presence of more numbers of leguminous plants. There is also a lower rate of leaching in mature forest. Nitrogen content was found higher compared to the findings in other areas (Marasini 2003).

Phosphorous content in all the three sectors was relatively low compared to the findings of other workers in different locations. Phosphorus content rises up due to the forest fire. In the present study area, no records of major forest fires were found. Bhatnagar (1965) reported that potassium content in soil was higher in dense sal forest. The present finding shows the range of potassium from 199.76 to $208.66 \mathrm{~kg} \mathrm{ha}^{-1}$. Phosphorous is negatively correlated with Potassium $(\mathrm{t}=-0.164)$ and water rising capacity is negatively correlated with water holding capacity $(\mathrm{t}=-0.895)$. Soil nutrients in Sector I and Sector II was found negatively correlated with soil water drainage ( $\mathrm{t}=-$ 0.986 and -0.944 respectively).

Regarding the soil drainage, highest water percolation and rising capacity was found at Sector I, as the soil was sandy and clayey, and most favourable for regenerating forest (Table 4). In case of water holding capacity, the trend altered with highest percentage for Sector III (41.75). As cited by Aryal (1997), water holding capacity increases with increase of clay particles. Since the land was degraded and barren in Sector III, the soil was clayey which holds more water. Soil colour for 
Sector I was dark grey indicating more humus content because of the deposition of original forest litter. The soil texture was found to be generally sandy to sandy loam which matches with the report of Sigdel (1994) in sal forest.

\section{CONCLUSION}

The ground diversity in Sector I was highest and the Sector III was recorded with lowest diversity. The tree species in Sector I was most dominant, but contrastingly herb and shrub dominance was seen higher in Sector III because of high frequency of species which grow on dry areas. Disturbance was visible by both natural and anthropogenic factors. Natural disturbance included flood, landslide and overgrazing. Anthropogenic disturbance was due to the illegal felling of trees for timber by local contractors.

\section{ACKNOWLEDGEMENT}

IUCN Nepal and Cornell Nepal Foundation, Cornell University, USA are thankfully acknowledged for financial support. Sincere thanks to Dr. R.K.P. Yadav for comments and suggestions on the manuscript.

\section{REFERENCES}

Adhikari, B.S., H.S. Rikhari, Y.S. Rawat and S.P. Singh. 1991. High altitude forest composition, diversity and profile structure in a part of Kumaun Himalaya. Tropical Ecology 32(1):86-97.

Amatya, S.M. and K.R. Shrestha. 2002. Nepal Forestry Hand Book. FORSPA, RAOBangoko, Oct. 2002.

Aryal, B. 1997. Vegetation Analysis of Royal Bardia National Park. M.Sc. Dissertation Central Department of Botany, Tribhuvan University, Nepal.

Bhatnagar, H.P. 1965. Ecological-Physiological studies of sal occurring in different forest of Uttar Pradesh. Ph.D. Thesis, Botany Department, Agra University, India.
Bhuju, D. and P. Yonzon 2000. Floristic composition, forest structure and regeneration of the churiya forest, eastern Nepal. A report submitted to Nature Conservation Society, Japan. Resources Himalayan, Kathmandu, Nepal, pp. 24-38.

Butler, M.D 1955. Conserving Soil. D. Von Nostrand Co-inc. Princeton, New Jersey.

Giri, A., B. Aryal, B. Bhattarai, S.K. Ghimire, K.K. Shrestha and P.K. Jha. 1999. Vegetation composition, biomass production, regeneration in Shorea robusta forest in Royal Bardia National Park. Nepal Journal of Science and Technology 1:47-56.

Marasini, S. 2003. Vegetation analysis of Churiya forest in Rupandehi, Nepal. M.Sc. Dissertation, Central Department of Botany, Tribhuvan University, Kathmandu, Nepal.

Pandey, P.K. 2001. Quantitative vegetation analysis as per aspect and altitude, and regeneration behaviour of tree species in Garhwal Himalayan Forest. Annals of Forestry 9(1):39-52.

Pant, A. 1997. A comparative study of vegetation and natural regeneration of two hill Sal forest (1) Community Forest and (2) Degraded Forest. M.Sc. Dissertation, Central Department of Botany, Tribhuvan University, Kathmandu Nepal.

Sai, V.S. and M. Mishra. 1986. Comparision of some indices and species diversity in the estimation of the actual diversity in the tropical forests. Tropical Ecology 27(2):195-201.

Shrestha, B.K. 2003. Phytoecology of Barandabhar Forest, Chitwan, Nepal. M.Sc. Disseration, Central Department of Botany, Tribhuvan University, Kathmandu, Nepal.

Sigdel, E.R. 1994. Physio-chemical properties of soil in Royal Chitwan National Park. M.Sc. dissertation, Central Department of Botany, Tribhuvan University, Kathmandu, Nepal.

Stainton, J.D.A. 1972. Forests of Nepal. John Musray, London, $181 \mathrm{pp}$. 